\title{
Bioavailability, distribution and clearance of tracheally-instilled and gavaged uncoated or silica-coated zinc oxide nanoparticles
}

Nagarjun V Konduru ${ }^{\dagger}$, Kimberly M Murdaugh ${ }^{\dagger}$, Georgios A Sotiriou, Thomas C Donaghey, Philip Demokritou, Joseph D Brain and Ramon M Molina*

\begin{abstract}
Background: Nanoparticle pharmacokinetics and biological effects are influenced by several factors. We assessed the effects of amorphous $\mathrm{SiO}_{2}$ coating on the pharmacokinetics of zinc oxide nanoparticles ( $\mathrm{ZnO} N P s$ ) following intratracheal (IT) instillation and gavage in rats.

Methods: Uncoated and $\mathrm{SiO}_{2}$-coated $\mathrm{ZnO}$ NPs were neutron-activated and IT-instilled at $1 \mathrm{mg} / \mathrm{kg}$ or gavaged at $5 \mathrm{mg} / \mathrm{kg}$. Rats were followed over 28 days post-IT, and over 7 days post-gavage. Tissue samples were analyzed for ${ }^{65} \mathrm{Zn}$ radioactivity. Pulmonary responses to instilled NPs were also evaluated at 24 hours.

Results: $\mathrm{SiO}_{2}$-coated $\mathrm{ZnO}$ elicited significantly higher inflammatory responses than uncoated NPs. Pulmonary clearance of both ${ }^{65} \mathrm{ZnO} N$ Ss was biphasic with a rapid initial $\mathrm{t}_{1 / 2}\left(0.2-0.3\right.$ hours), and a slower terminal $\mathrm{t}_{1 / 2}$ of 1.2 days $\left(\mathrm{SiO}_{2}\right.$-coated $\left.\mathrm{ZnO}\right)$ and 1.7 days $(\mathrm{ZnO})$. Both NPs were almost completely cleared by day $7(>98 \%)$. With IT-instilled ${ }^{65} \mathrm{ZnO} N$ ss, significantly more ${ }^{65} \mathrm{Zn}$ was found in skeletal muscle, liver, skin, kidneys, cecum and blood on day 2 in uncoated than $\mathrm{SiO}_{2}$-coated NPs. By 28 days, extrapulmonary levels of ${ }^{65} \mathrm{Zn}$ from both NPs significantly decreased. However, ${ }^{65} \mathrm{Zn}$ levels in skeletal muscle, skin and blood remained higher from uncoated NPs. Interestingly, ${ }^{65} \mathrm{Zn}$ levels in bone marrow and thoracic lymph nodes were higher from coated ${ }^{65} \mathrm{ZnO}$ NPs. More ${ }^{65} \mathrm{Zn}$ was excreted in the urine from rats instilled with $\mathrm{SiO}_{2}$-coated ${ }^{65} \mathrm{ZnO}$ NPs. After 7 days post-gavage, only $7.4 \%$ (uncoated) and $6.7 \%$ (coated) of ${ }^{65} \mathrm{Zn}$ dose were measured in all tissues combined. As with instilled NPs, after gavage significantly more ${ }^{65} \mathrm{Zn}$ was measured in skeletal muscle from uncoated NPs and less in thoracic lymph nodes. More ${ }^{65} \mathrm{Zn}$ was excreted in the urine and feces with coated than uncoated ${ }^{65} \mathrm{ZnO}$ NPs. However, over $95 \%$ of the total dose of both NPs was eliminated in the feces by day 7 .
\end{abstract}

Conclusions: Although $\mathrm{SiO}_{2}$-coated $\mathrm{ZnO} N$ Ps were more inflammogenic, the overall lung clearance rate was not affected. However, $\mathrm{SiO}_{2}$ coating altered the tissue distribution of ${ }^{65} \mathrm{Zn}$ in some extrapulmonary tissues. For both IT instillation and gavage administration, $\mathrm{SiO}_{2}$ coating enhanced transport of ${ }^{65} \mathrm{Zn}$ to thoracic lymph nodes and decreased transport to the skeletal muscle.

Keywords: Zinc oxide, Nanoparticles, Pharmacokinetics, Bioavailability, Silica coating, Nanotoxicology

\footnotetext{
* Correspondence: rmolina@hsph.harvard.edu

${ }^{\dagger}$ Equal contributors

Center for Nanotechnology and Nanotoxicology, Molecular and Integrative Physiological Sciences Program, Department of Environmental Health, School of Public Health, Harvard University, 665 Huntington Avenue, Boston, MA 02115, USA
}

\section{Biomed Central}

(c) 2014 Konduru et al.; licensee BioMed Central Ltd. This is an Open Access article distributed under the terms of the Creative Commons Attribution License (http://creativecommons.org/licenses/by/4.0), which permits unrestricted use, distribution, and reproduction in any medium, provided the original work is properly credited. The Creative Commons Public Domain Dedication waiver (http://creativecommons.org/publicdomain/zero/1.0/) applies to the data made available in this article, unless otherwise stated. 


\section{Background}

Zinc oxide nanoparticles ( $\mathrm{ZnO} \mathrm{NPs}$ ) are widely used in consumer products, including ceramics, cosmetics, plastics, sealants, toners and foods [1]. They are a common component in a range of technologies, including sensors, light emitting diodes, and solar cells due to their semiconducting and optical properties [2]. ZnO NPs filter both UV-A and UV-B radiation but remain transparent in the visible spectrum [3]. For this reason, $\mathrm{ZnO}$ NPs are commonly added to sunscreens [4] and other cosmetic products. Furthermore, advanced technologies have made the large-scale production of $\mathrm{ZnO}$ NPs possible [5]. Health concerns have been raised due to the growing evidence of the potential toxicity of $\mathrm{ZnO}$ NPs. Reduced pulmonary function in humans was observed 24 hours after inhalation of ultrafine $(<100 \mathrm{~nm}) \mathrm{ZnO}$ [6]. It has also been shown to cause DNA damage in HepG2 cells and neurotoxicity due to the formation of reactive oxygen species (ROS) [7,8]. Recently, others and we have demonstrated that $\mathrm{ZnO}$ NPs can cause DNA damage in TK6 and H9T3 cells $[9,10]$. ZnO NPs dissolve in aqueous solutions, releasing $\mathrm{Zn}^{2+}$ ions that may in turn cause cytotoxicity and DNA damage to cells $[9,11-13]$.

Studies have shown that changing the surface characteristics of certain NPs may alter the biologic responses of cells $[14,15]$. Developing strategies to reduce the toxicity of $\mathrm{ZnO}$ NPs without changing their core properties (safer-by-design approach) is an active area of research. Xia et al. [16] showed that doping $\mathrm{ZnO}$ NPs with iron could reduce the rate of $\mathrm{ZnO}$ dissolution and the toxic effects in zebra fish embryos and rat and mouse lungs [16]. We also showed that encapsulation of $\mathrm{ZnO}$ NPs with amorphous $\mathrm{SiO}_{2}$ reduced the dissolution of $\mathrm{Zn}^{2+}$ ions in biological media, and reduced cell cytotoxicity and DNA damage in vitro [17]. Surface characteristics of NPs, such as their chemical and molecular structure, influence their pharmacokinetic behavior [18-20]. Surface chemistry influences the adsorption of phospholipids, proteins and other components of lung surfactants in the formation of a particle corona, which may regulate the overall nanoparticle pharmacokinetics and biological responses [19]. Coronas have been shown to influence the dynamics of cellular uptake, localization, biodistribution, and biological effects of NPs [21,22].

Coating of NPs with amorphous silica is a promising technique to enhance colloidal stability and biocompatibility for theranostics [23,24]. A recent study by Chen et al. showed that coating gold nanorods with silica can amplify the photoacoustic response without altering optical absorption [25]. Furthermore, coating magnetic NPs with amorphous silica enhances particle stability and reduces its cytotoxicity in a human bronchial epithelium cell line model [26]. Amorphous $\mathrm{SiO}_{2}$ is generally considered relatively biologically inert [27], and is commonly used in cosmetic and personal care products, and as a negative control in some nanoparticle toxicity screening assays [28]. However, Napierska et al. demonstrated the size-dependent cytotoxic effects of amorphous silica in vitro [29]. They concluded that the surface area of amorphous silica is an important determinant of cytotoxicity. An in vivo study using a rat model demonstrated that the pulmonary toxicity and inflammatory responses to amorphous silica are transient [30]. Moreover, $\mathrm{SiO}_{2}$-coated nanoceria induced minimal lung injury and inflammation [31]. It has also been demonstrated that $\mathrm{SiO}_{2}$ coating improves nanoparticle biocompatibility in vitro for a variety of nanomaterials, including $\mathrm{Ag}$ [32], $\mathrm{Y}_{2} \mathrm{O}_{3}$ [33], and $\mathrm{ZnO}$ [17]. We have recently developed methods for the gas-phase synthesis of metal and metal oxide NPs by a modified flame spray pyrolysis (FSP) reactor. Coating metal oxide NPs with amorphous $\mathrm{SiO}_{2}$ involves the encapsulation of the core NPs in flight with a nanothin amorphous $\mathrm{SiO}_{2}$ layer [34]. An important advantage of flame-made NPs is their high purity. Flame synthesis is a high-temperature process that leaves no organic contamination on the particle surface. Furthermore, the presence of $\mathrm{SiO}_{2}$ does not influence the optoelectronic properties of the core $\mathrm{ZnO}$ nanorods. Thus, they retain their desired high transparency in the visible spectrum and UV absorption rendering them suitable for UV blocking applications [17]. The $\mathrm{SiO}_{2}$ coating has been demonstrated to reduce $\mathrm{ZnO}$ nanorod toxicity by mitigating their dissolution and generation of ions in solutions, and by preventing the immediate contact between the core particle and mammalian cells. For $\mathrm{ZnO}$ NPs, such a hermetic $\mathrm{SiO}_{2}$ coating reduces $\mathrm{ZnO}$ dissolution while preserving the optical properties and band-gap energy of the $\mathrm{ZnO}$ core [17].

Studies examining nanoparticle structure-pharmacokinetic relationships have established that plasma protein binding profiles correlate with circulation half-lives [27]. However, studies evaluating the relationship between surface modifications, lung clearance kinetics, and pulmonary effects are lacking. Thus, we sought to study the effects of amorphous $\mathrm{SiO}_{2}$ coating on $\mathrm{ZnO}$ pulmonary effects and on pharmacokinetics of ${ }^{65} \mathrm{Zn}$ when radioactive ${ }^{65} \mathrm{ZnO}$ and $\mathrm{SiO}_{2}$-coated ${ }^{65} \mathrm{ZnO}$ nanorods are administered by intratracheal instillation (IT) and gavage. We explored how the $\mathrm{SiO}_{2}$ coating affected acute toxicity and inflammatory responses in the lungs, as well as ${ }^{65} \mathrm{Zn}$ clearance and tissue distribution after IT instillation over a period of 28 days. The translocation of the ${ }^{65} \mathrm{Zn}$ from the stomach to other organs was also quantified for up to 7 days after gavage. Finally, we examined how the $\mathrm{SiO}_{2}$ coating affected the urinary and fecal excretion of ${ }^{65} \mathrm{Zn}$ during the entire observation period. 


\section{Results}

Synthesis and characterization of $\mathrm{ZnO}$ and $\mathrm{SiO}_{2}$-coated ZnO NPs

Uncoated and $\mathrm{SiO}_{2}$-coated $\mathrm{ZnO} \mathrm{NPs}$ were made by flame spray pyrolysis using the Versatile Engineered Nanomaterial Generation System at Harvard University $[35,17]$. The detailed physicochemical and morphological characterization of these NPs was reported earlier $[36,17]$. The $\mathrm{ZnO}$ primary NPs had a rod-like shape with an aspect ratio of $2: 1$ to $8: 1$ (Figure 1) [37,17]. Flamemade nanoparticles typically exhibit a lognormal size distribution with a geometric standard deviation of $\sigma_{\mathbf{g}}=$ 1.45 [38]. To create the $\mathrm{SiO}_{2}$-coated $\mathrm{ZnO}$ nanorods, a nanothin $(\sim 4.6 \pm 2.5 \mathrm{~nm})$ amorphous $\mathrm{SiO}_{2}$ layer encapsulated the $\mathrm{ZnO}$ core [17] (Figure 1B). The amorphous nature of the silica coating was verified by X-ray diffraction (XRD) and electron microscopy analyses [17]. The average crystal size of uncoated and $\mathrm{SiO}_{2}$-coated NPs were 29 and $28 \mathrm{~nm}$, respectively [39]. Their specific surface areas (SSA) were $41 \mathrm{~m}^{2} / \mathrm{g}$ (uncoated) and $55 \mathrm{~m}^{2} / \mathrm{g}$ $\left(\mathrm{SiO}_{2}\right.$-coated) [40]. The lower density of $\mathrm{SiO}_{2}$ compared to $\mathrm{ZnO}$ contributes to the higher SSA of the $\mathrm{SiO}_{2}$-coated $\mathrm{ZnO}$ than uncoated NPs. The extent of the $\mathrm{SiO}_{2}$ coating was assessed by X-ray photoelectron spectroscopy and photocatalytic experiments. These data showed that less than $5 \%$ of $\mathrm{ZnO}$ NPs were uncoated, as some of the freshly-formed core $\mathrm{ZnO}$ NPs may escape the coating process [41,17]. Furthermore, the $\mathrm{ZnO}$ dissolution of the $\mathrm{SiO}_{2}$-coated nanorods was significantly lower than the uncoated NPs in culture medium over $24 \mathrm{~h}$ [17]. The $\mathrm{Zn}^{2+}$ ion concentration reached equilibrium after 6 hours for the coated NPs $(\sim 20 \%)$, while the uncoated ones dissolved at a constant rate up to 24 hours [17]. For both IT and gavage routes, the NPs were dispersed in deionized water by sonication at $242 \mathrm{~J} / \mathrm{ml}$. The hydrodynamic diameters were $165 \pm 3 \mathrm{~nm}\left(\mathrm{SiO}_{2}\right.$-coated $)$ and $221 \pm$ $3 \mathrm{~nm}$ (uncoated). The zeta potential values in these suspensions were $23 \pm 0.4 \mathrm{mV}$ (uncoated) and $-16.2 \pm$ $1.2\left(\mathrm{SiO}_{2}\right.$-coated). The zeta potential differences between these two types of NPs were observed at a $\mathrm{pH}$ range of 2.5-8.0 [17], which includes the $\mathrm{pH}$ conditions in the airways/alveoli and small and large intestines. The postirradiation hydrodynamic diameter and zeta potential in water suspension were similar to those of pristine NPs used in the lung toxicity/inflammation experiments.

\section{Pulmonary responses to intratracheally instilled $\mathrm{ZnO}$ and $\mathrm{SiO}_{2}$-coated $\mathrm{ZnO}$}

We compared the pulmonary responses to uncoated versus $\mathrm{SiO}_{2}$-coated $\mathrm{ZnO}$ NPs at 24 hours after IT instillation in rats. Groups of 4-6 rats received $0,0.2$ or $1 \mathrm{mg} / \mathrm{kg}$ of either type of NP. We found that IT-instilled coated and uncoated $\mathrm{ZnO}$ NPs induced a dose-dependent injury and inflammation evident by increased neutrophils, elevated levels of myeloperoxidase (MPO), albumin and lactate dehydrogenase $(\mathrm{LDH})$ in the bronchoalveolar lavage (BAL) fluid at 24 hours post-instillation (Figure 2). At the lower dose of $0.2 \mathrm{mg} / \mathrm{kg}$, only the $\mathrm{SiO}_{2}$-coated $\mathrm{ZnO}$ instilled rats $(\mathrm{n}=4)$ showed elevated neutrophils, LDH, MPO, and albumin levels. But at $1 \mathrm{mg} / \mathrm{kg}$, both types of NPs induced injury and inflammation to the same extent, except that MPO was higher in rats instilled with $\mathrm{SiO}_{2}$-coated $\mathrm{ZnO}$ NPs.

\section{Pharmacokinetics of intratracheally-instilled uncoated or $\mathrm{SiO}_{2}$-coated ${ }^{65} \mathrm{ZnO}$ NPs}

Clearance of instilled uncoated or $\mathrm{SiO}_{2}$-coated ${ }^{65} \mathrm{ZnO}$ NPs from the lungs is shown in Figure 3. Overall, both ${ }^{65} \mathrm{ZnO}$ $\mathrm{NPs}$ and $\mathrm{SiO}_{2}$-coated ${ }^{65} \mathrm{ZnO}$ NPs exhibited a biphasic clearance with a rapid initial phase $\left(\mathrm{t}_{1 / 2}:{ }^{65} \mathrm{ZnO}=0.3\right.$ hours; $\mathrm{SiO}_{2}$-coated ${ }^{65} \mathrm{ZnO}=0.2$ hours) and a slower terminal phase $\left(\mathrm{t}_{1 / 2}:{ }^{65} \mathrm{ZnO}=42\right.$ hours; $\mathrm{SiO}_{2}$-coated ${ }^{65} \mathrm{ZnO}=29$ hours $)$. No significant difference was observed on the initial clearance between the two types of NPs. At 2 days, $18.1 \pm 2.1 \%$ and

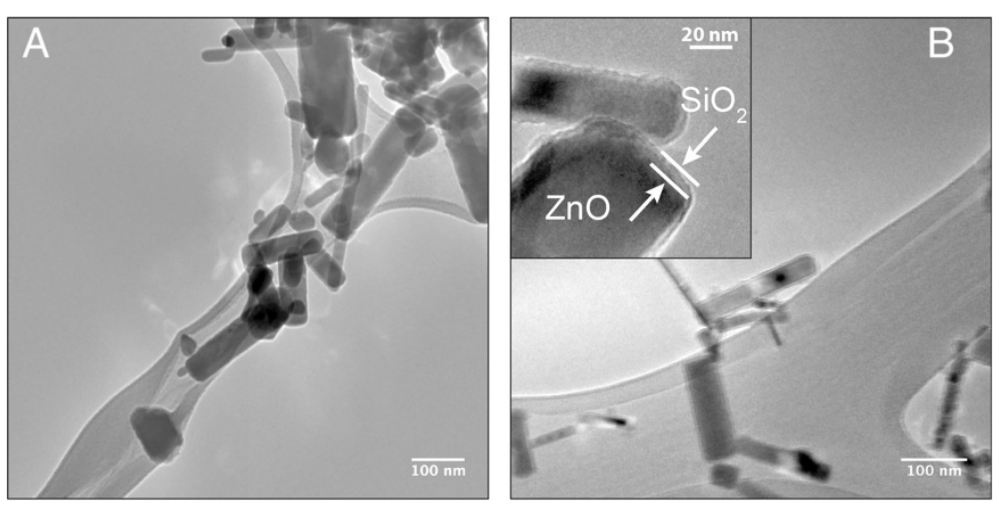

Figure 1 Physicochemical characterization of test materials. Transmission electron micrograph of uncoated $\mathrm{ZnO}(\mathbf{A})$ and $\mathrm{SiO}{ }_{2}-\mathrm{Coated} \mathrm{ZnO}$ (B) NPs. The thin silica coating of approximately $5 \mathrm{~nm}$ is shown in B, inset. 

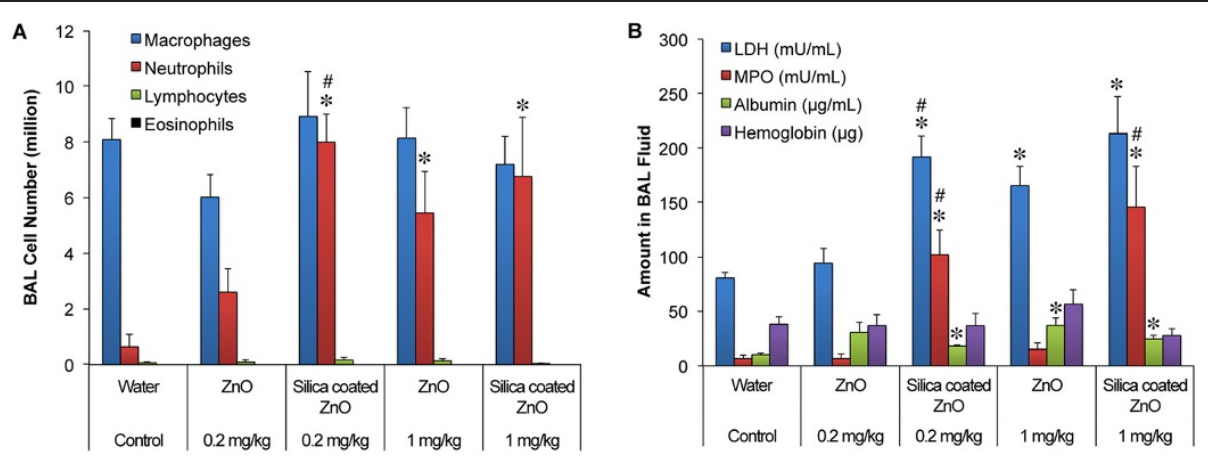

Figure 2 Cellular and biochemical parameters of lung injury and inflammation in bronchoalveolar lavage (BAL). Tracheally instilled $\mathrm{ZnO}$ and $\mathrm{SiO}_{2}$-coated $\mathrm{ZnO}$ induced a dose-dependent lung injury and inflammation at 24 hours. (A) Significant increases in BAL neutrophils were observed at $1 \mathrm{mg} / \mathrm{kg}$ of both NPs ( $\mathrm{n}=6 / \mathrm{group})$. At the lower dose of $0.2 \mathrm{mg} / \mathrm{kg}(\mathrm{n}=4-6 / \mathrm{group})$, only the $\mathrm{SiO}_{2}$-coated $\mathrm{ZnO}(\mathrm{n}=4)$ induced significant neutrophil influx in the lungs. (B) Similarly, significant increases in LDH, myeloperoxidase and albumin were observed at $1 \mathrm{mg} / \mathrm{kg}$ of both NPs, and at $0.2 \mathrm{mg}$ of $\mathrm{SiO}_{2}$-coated $\mathrm{ZnO}$. ( ${ }^{*} \mathrm{P}<0.05$, vs. control, \#P $<0.05$, $\mathrm{SiO}_{2}$-coated $\mathrm{ZnO}$ versus $\left.\mathrm{ZnO}\right)$.

$16.1 \pm 2.0 \%$ remained in the lungs for the $\mathrm{SiO}_{2}$-coated and uncoated ${ }^{65} \mathrm{ZnO}$ NPs, respectively. At 7 and 28 days post-IT instillation, we observed statistically significant but small (in magnitude) differences. At 28 days, only $0.14 \pm$ $0.01 \%$ of $\mathrm{SiO}_{2}$-coated ${ }^{65} \mathrm{ZnO}$ and $0.28 \pm 0.05 \%$ of the uncoated ${ }^{65} \mathrm{ZnO}$ NPs remained in the lungs.

However, analyses of the selected extrapulmonary tissues showed significant differences (Figure 4). Even at the earliest time point of 5 minutes post-IT instillation, significantly more ${ }^{65} \mathrm{Zn}$ was detected in the blood $(0.47 \%$ vs. $0.25 \%)$ and heart $(0.03 \%$ vs. $0.01 \%)$ of rats instilled with the uncoated ${ }^{65} \mathrm{ZnO}$ NPs. These tissue differences

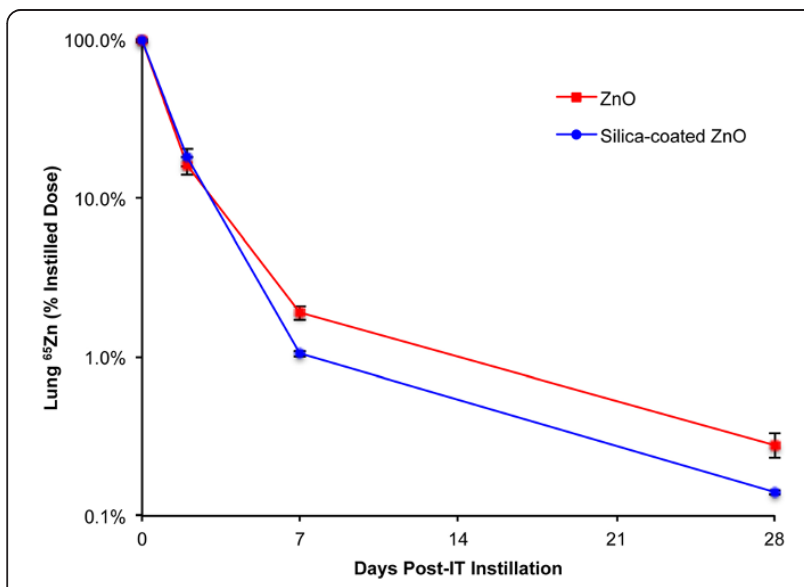

Figure 3 Lung clearance of ${ }^{65} \mathrm{Zn}$ post-IT instillation of ${ }^{65} \mathrm{ZnO}$ and $\mathrm{SiO}_{2}$-coated ${ }^{65} \mathrm{ZnO}$ NPs. The percentages of instilled ${ }^{65} \mathrm{Zn}$ measured in the whole lungs are shown over a period of 28 days. The clearance of ${ }^{65} \mathrm{Zn}$ was rapid with only $16-18 \%$ of dose remaining at 2 days. By day 7 , only $1.1 \%\left(\mathrm{SiO}_{2}\right.$-coated $\left.{ }^{65} \mathrm{ZnO} \mathrm{NPs}\right)$ and $1.9 \%$ $\left({ }^{65} \mathrm{ZnO} \mathrm{NPs}\right)$ were measured in the lungs. And by the end of experiment, ${ }^{65} \mathrm{Zn}$ was nearly gone (less than $0.3 \%$ of dose). Although statistically higher levels of ${ }^{65} \mathrm{ZnO}$ NPs than of $\mathrm{SiO}_{2}$-coated ${ }^{65} \mathrm{ZnO}$ NPs remained in the lungs at 7 and 28 days, the graphs show nearly identical clearance kinetics. ( $n=8$ rats at 5 minutes, 2 days, and 7 days, $n=5$ at 28 days). became more pronounced at later time points. At 2 days post-IT instillation, more ${ }^{65} \mathrm{Zn}$ from uncoated ${ }^{65} \mathrm{ZnO}$ NPs translocated to the blood, skeletal muscle, kidneys, heart, liver and cecum than from $\mathrm{SiO}_{2}$-coated ${ }^{65} \mathrm{ZnO}$ NPs (Table 1). At 7 and 28 days, the overall differences in the ${ }^{65} \mathrm{Zn}$ contents in these tissues remained the same. As shown in Tables 2 and 3, significantly higher fractions of the ${ }^{65} \mathrm{Zn}$ from uncoated ${ }^{65} \mathrm{ZnO}$ NPs than from $\mathrm{SiO}_{2}$-coated ${ }^{65} \mathrm{ZnO}$ NPs were found in the blood, skeletal muscle, heart, liver and skin. Interestingly, higher percentages of ${ }^{65} \mathrm{Zn}$ dose from the $\mathrm{SiO}_{2}$-coated ${ }^{65} \mathrm{ZnO}$ NPs were found in the thoracic lymph nodes and bone marrow (Tables 2 and 4). Radioactive ${ }^{65} \mathrm{Zn}$ levels decreased from 2 to 28 days in all tissues except bone, where it increased for both types of NPs. Additionally, we found that the total recovered ${ }^{65} \mathrm{Zn}$ in examined tissues, feces and urine was significantly higher in uncoated than $\mathrm{SiO}_{2}$-coated ${ }^{65} \mathrm{ZnO}$ NPs (Tables 1,23 and Figure 5). Since the thoracic lymph nodes had higher ${ }^{65} \mathrm{Zn}$ in the latter group at all time points (Tables 1,2 and 3), we speculate that the unaccounted radioactivity may have been in other lymph nodes as well as organs not analyzed such as adipose tissue, pancreas, adrenals, teeth, nails, tendons, and nasal tissues.

Urinary excretion of ${ }^{65} \mathrm{Zn}$ was much lower than fecal excretion in both groups. The urinary excretion of ${ }^{65} \mathrm{Zn}$ in rats instilled with $\mathrm{SiO}_{2}$-coated ${ }^{65} \mathrm{ZnO}$ NPs was significantly higher than in those instilled with uncoated ${ }^{65} \mathrm{ZnO}$ NPs (Figure 5B). Although the fecal excretion rates appeared similar, slightly but significantly more ${ }^{65} \mathrm{Zn}(50.04 \pm 0.96 \%$ vs. $46.68 \pm 0.76 \%$ ) was eliminated via the feces over 28 days in rats instilled with uncoated ${ }^{65} \mathrm{ZnO}$ NPs (Figure $5 \mathrm{~A}$ ).

\section{Pharmacokinetics of gavaged uncoated or $\mathrm{SiO}_{2}$-coated ${ }^{65}$ ZnO NPs}

Absorption of ${ }^{65} \mathrm{Zn}$ from the gut was studied at 5 minutes and 7 days post-gavage of uncoated or $\mathrm{SiO}_{2}$-coated ${ }^{65} \mathrm{ZnO}$ 


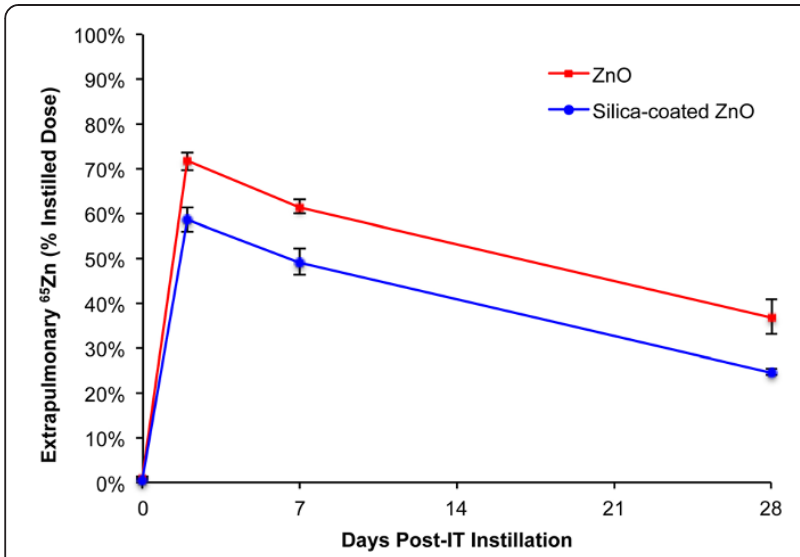

Figure 4 Extrapulmonary distribution of ${ }^{65} \mathrm{Zn}$ post-IT instillation of ${ }^{65} \mathrm{ZnO}$ and $\mathrm{SiO}_{2}$-coated ${ }^{65} \mathrm{ZnO}$ NPs. Data are $\%$ of instilled dose recovered in all secondary tissues examined. It included blood, thoracic lymph nodes, bone, bone marrow, skin, brain, skeletal muscle, testes, kidneys, heart, liver, and the gastrointestinal tract. There was a rapid absorption and accumulation of ${ }^{65} \mathrm{Zn}$ in secondary tissues. At day 2 , $59-72 \%$ of the dose was detected in extrapulmonary organs. Then, ${ }^{65} \mathrm{Zn}$ levels decreased over time to $25-37 \%$ by day 28 . Significantly more ${ }^{65} \mathrm{Zn}$ was detected in secondary organs at all time points in rats instilled with uncoated ${ }^{65} \mathrm{ZnO}$ NPs.

Table 1 Tissue distribution of ${ }^{65} \mathrm{Zn}$ at 2 days after intratracheal instillation of ${ }^{65} \mathrm{ZnO}$ or $\mathrm{SiO}_{2}$-coated ${ }^{65} \mathrm{ZnO}$ NPs in rats

\begin{tabular}{lll}
\hline & $\begin{array}{l}\text { ZnO } \\
\text { Mean } \pm \text { SE }\end{array}$ & $\begin{array}{l}\text { SiO }_{2} \text {-coated ZnO } \\
\text { Mean } \pm \text { SE }\end{array}$ \\
\hline Lungs & $16.08 \pm 2.00$ & $18.09 \pm 2.17$ \\
Blood & $2.54 \pm 0.07^{*}$ & $2.22 \pm 0.08$ \\
Lymph nodes & $0.63 \pm 0.23$ & $0.49 \pm 0.04$ \\
Bone marrow & $3.37 \pm 0.32$ & $2.89 \pm 0.15$ \\
Bone & $9.59 \pm 0.46$ & $9.25 \pm 0.29$ \\
Skin & $11.30 \pm 1.00$ & $12.52 \pm 0.77$ \\
Brain & $0.17 \pm 0.01$ & $0.19 \pm 0.01 \#$ \\
Skeletal muscle & $14.22 \pm 0.77^{*}$ & $6.39 \pm 2.44$ \\
Testes & $0.84 \pm 0.05$ & $0.78 \pm 0.04$ \\
Kidneys & $2.05 \pm 0.07^{*}$ & $1.74 \pm 0.03$ \\
Spleen & $0.50 \pm 0.02$ & $0.44 \pm 0.02$ \\
Heart & $0.47 \pm 0.04^{*}$ & $0.36 \pm 0.01$ \\
Liver & $12.23 \pm 0.24^{*}$ & $9.88 \pm 0.38$ \\
Stomach & $1.01 \pm 0.14$ & $0.78 \pm 0.02$ \\
Small intestine & $7.37 \pm 0.32$ & $6.89 \pm 0.20$ \\
Large intestine & $2.08 \pm 0.21$ & $1.91 \pm 0.12$ \\
Cecum & $3.42 \pm 0.22^{*}$ & $2.35 \pm 0.25$ \\
Total recovered & $87.78 \pm 2.35^{*}$ & $76.78 \pm 2.84$ \\
\hline Data are mean &
\end{tabular}

Data are mean \pm SE\% instilled dose, $n=8 /$ group.

Total recovered $=$ sum of ${ }^{65} \mathrm{Zn}$ in analyzed organs, feces and urine.

*P $<0.05, \mathrm{ZnO}>\mathrm{SiO}_{2}$-coated $\mathrm{ZnO}$.

\# P $<0.05, \mathrm{SiO}_{2}$-coated $\mathrm{ZnO}>\mathrm{ZnO}$.
Table 2 Tissue distribution of ${ }^{65} \mathrm{Zn}$ at 7 days after intratracheal instillation of ${ }^{65} \mathrm{ZnO}$ or $\mathrm{SiO}_{2}$-coated ${ }^{65} \mathrm{ZnO}$ NPs in rats

\begin{tabular}{lll}
\hline & $\begin{array}{l}{ }^{65} \mathrm{ZnO} \\
\text { Mean } \pm \text { SE }\end{array}$ & $\begin{array}{l}\text { SiO }_{2} \text {-coated } \\
\text { Mean } \pm \text { SE }\end{array}$ \\
\hline Lungs & $1.90 \pm 0.18$ & $1.05 \pm 0.04$ \\
Blood & $2.13 \pm 0.05^{*}$ & $1.79 \pm 0.07$ \\
Lymph nodes & $0.18 \pm 0.02$ & $0.31 \pm 0.05 \#$ \\
Bone marrow & $3.70 \pm 0.28$ & $3.38 \pm 0.16$ \\
Bone & $12.12 \pm 0.53$ & $12.21 \pm 0.84$ \\
Skin & $10.02 \pm 0.49$ & $10.55 \pm 0.80$ \\
Brain & $0.25 \pm 0.01$ & $0.27 \pm 0.01$ \\
Skeletal muscle & $19.81 \pm 0.84^{*}$ & $8.34 \pm 3.45$ \\
Testes & $1.27 \pm 0.06$ & $1.23 \pm 0.03$ \\
Kidneys & $0.75 \pm 0.03$ & $0.69 \pm 0.02$ \\
Spleen & $0.21 \pm 0.01$ & $0.20 \pm 0.01$ \\
Heart & $0.27 \pm 0.01^{*}$ & $0.23 \pm 0.01$ \\
Liver & $5.80 \pm 0.13^{*}$ & $5.19 \pm 0.25$ \\
Stomach & $0.66 \pm 0.02$ & $0.66 \pm 0.03$ \\
Small intestine & $2.83 \pm 0.10$ & $2.53 \pm 0.12$ \\
Large intestine & $0.84 \pm 0.07$ & $0.83 \pm 0.05$ \\
Cecum & $1.15 \pm 0.06$ & $1.04 \pm 0.09$ \\
Total recovered & $81.33 \pm 6.51^{*}$ & $69.91 \pm 3.33$ \\
\hline Data a mean &
\end{tabular}

Data are mean $\pm S E \%$ instilled dose, $n=8 /$ group.

Total recovered $=$ sum of ${ }^{65} \mathrm{Zn}$ in analyzed organs, feces and urine.

*P $<0.05, \mathrm{ZnO}>\mathrm{SiO}_{2}$-coated $\mathrm{ZnO}$.

\# $\mathrm{P}<0.05, \mathrm{SiO}_{2}$-coated $\mathrm{ZnO}>\mathrm{ZnO}$.

NPs. Nearly $100 \%$ of the dose was recovered at 5 minutes in the stomach for both types of NPs (Figure 6A). The ${ }^{65} \mathrm{Zn}$ levels in tissues other than the gastrointestinal tract were much lower $(0.3 \%$ for uncoated, $0.05 \%$ for coated $\left.{ }^{65} \mathrm{ZnO} \mathrm{NPs}\right)$. However, significantly higher percentages of total dose were still detected in the blood, bone marrow, skin, testes, kidneys, spleen and liver in rats instilled with uncoated ${ }^{65} \mathrm{ZnO}$ NPs (data not shown). After 7 days, low levels of ${ }^{65} \mathrm{Zn}$ from both types of NPs ( $<1 \%$ original dose) were measured in all organs except the bone, skeletal muscle and skin (Figure 6B, Table 4). Higher levels of ${ }^{65} \mathrm{Zn}$ were observed in the skeletal muscle from uncoated than from coated ${ }^{65} \mathrm{ZnO}$ NPs at this time point (Table 4). However, similar to the IT-instillation data, the thoracic lymph nodes retained more ${ }^{65} \mathrm{Zn}$ from the $\mathrm{SiO}_{2}$-coated than the uncoated ${ }^{65} \mathrm{ZnO}$ NPs. Urinary excretion of ${ }^{65} \mathrm{Zn}$ was also much lower than fecal excretion post-gavage. The urinary excretion of ${ }^{65} \mathrm{Zn}$ in rats gavaged with $\mathrm{SiO}_{2}$-coated ${ }^{65} \mathrm{ZnO}$ NPs was significantly higher than in rats gavaged with uncoated ${ }^{65} \mathrm{ZnO}$ NPs (Figure 7B). The fecal excretion in the gavaged rats was higher than in IT-instilled rats. Despite a significant difference in fecal excretion during the first day post-gavage, nearly $95 \%$ of the dose for both types of NPs was excreted in the feces by day 7 (Figure 7A). 
Table 3 Tissue distribution of ${ }^{65} \mathrm{Zn}$ at 28 days after intratracheal instillation of ${ }^{65} \mathrm{ZnO}$ or $\mathrm{SiO}_{2}$-coated ${ }^{65} \mathrm{ZnO}$ NPs in rats

\begin{tabular}{lll}
\hline & $\begin{array}{l}{ }^{65} \mathrm{ZnO} \\
\text { Mean } \pm \mathrm{SE}\end{array}$ & $\begin{array}{l}\mathrm{SiO}_{2} \text {-coated } \\
\text { Mean } \pm \mathrm{SE}\end{array}$ \\
\hline Lungs & $0.28 \pm 0.05^{*}$ & $0.14 \pm 0.01$ \\
Blood & $0.79 \pm 0.05^{*}$ & $0.61 \pm 0.02$ \\
Lymph nodes & $0.03 \pm 0.005$ & $0.12 \pm 0.01 \#$ \\
Bone marrow & $2.30 \pm 0.12$ & $3.33 \pm 0.15 \#$ \\
Bone & $12.40 \pm 0.36$ & $13.59 \pm 0.52$ \\
Skin & $4.72 \pm 0.60^{*}$ & $3.26 \pm 0.13$ \\
Brain & $0.18 \pm 0.02$ & $0.15 \pm 0.01$ \\
Skeletal muscle & $13.27 \pm 3.02^{*}$ & $0.66 \pm 0.04$ \\
Testes & $0.49 \pm 0.03$ & $0.46 \pm 0.03$ \\
Kidneys & $0.19 \pm 0.01$ & $0.17 \pm 0.005$ \\
Spleen & $0.05 \pm 0.005$ & $0.04 \pm 0.003$ \\
Heart & $0.07 \pm 0.004^{*}$ & $0.06 \pm 0.002$ \\
Liver & $1.32 \pm 0.09$ & $1.14 \pm 0.02$ \\
Stomach & $0.20 \pm 0.01$ & $0.20 \pm 0.01$ \\
Small intestine & $0.63 \pm 0.05$ & $0.55 \pm 0.01$ \\
Large intestine & $0.19 \pm 0.02$ & $0.25 \pm 0.01 \#$ \\
Cecum & $0.23 \pm 0.02$ & $0.24 \pm 0.01$ \\
Total recovered & $88.20 \pm 4.36^{*}$ & $72.81 \pm 0.53$ \\
\hline Data are mean &
\end{tabular}

Data are mean \pm SE\% instilled dose, $n=5 /$ group.

Total recovered $=$ sum of ${ }^{65} \mathrm{Zn}$ in analyzed organs, feces and urine.

*P $<0.05, \mathrm{ZnO}>\mathrm{SiO}_{2}$-coated $\mathrm{ZnO}$.

\# $\mathrm{P}<0.05, \mathrm{SiO}_{2}$-coated $\mathrm{ZnO}>\mathrm{ZnO}$.

\section{Discussion}

Nanoparticles can be released into the workplace environment during production and handling of nanomaterials [42]. For example, studies have shown that ZnO NPs were released during an abrasion test of commercially available two-pack polyurethane coatings with ZnO NPs [43]. This suggests the likelihood of emission of NPs during activities related to handling of nano-enabled products. In this study we describe the acute pulmonary responses to $\mathrm{ZnO} \mathrm{NPs}$ and the pharmacokinetics of $\mathrm{Zn}$ from $\mathrm{ZnO}$ or $\mathrm{SiO}_{2}$-coated $\mathrm{ZnO}$ NPs in male Wistar Han rats. To track $\mathrm{Zn}$ for biokinetic studies in rats, we neutron activated the NPs to change the stable element ${ }^{64} \mathrm{Zn}$ into radioactive ${ }^{65} \mathrm{Zn}$, suitable for detection over long-term studies. The agglomerate size and zeta potential in water suspension were similar to those of pristine $\mathrm{ZnO}$ NPs. Using these radioactive NPs, we evaluated the influence of an amorphous silica coating on the clearance, bioavailability and excretion of ${ }^{65} \mathrm{Zn}$ following intratracheal instillation and gavage of ${ }^{65} \mathrm{ZnO}$ and $\mathrm{Si}$ coated ${ }^{65} \mathrm{ZnO}$ NPs. We have shown previously that the hermetic encapsulation of $\mathrm{ZnO}$ NPs with a thin layer of amorphous $\mathrm{SiO}_{2}$ reduces the dissolution of $\mathrm{Zn}^{2+}$ ions in biological media, DNA damage in vitro [17] and cellular
Table 4 Distribution of ${ }^{65} \mathrm{Zn} 7$ days after gavage

\begin{tabular}{lll} 
administration of ${ }^{{ }^{65}} \mathbf{Z n O}$ or $\mathbf{S i O}_{\mathbf{2}}$-coated & ${ }^{\mathbf{6 5}} \mathbf{Z n O} \mathbf{~ N P s}$ in rats \\
\hline & ${ }^{\mathbf{6 5}} \mathbf{Z n O}$ & $\mathbf{S i O}_{2}$-coated ${ }^{65} \mathbf{Z n O}$ \\
& Mean $\pm \mathrm{SE}$ & $\mathbf{M e a n} \pm \mathrm{SE}$ \\
\hline Lungs & $0.04 \pm 0.01$ & $0.06 \pm 0.01$ \\
Blood & $0.23 \pm 0.03$ & $0.22 \pm 0.04$ \\
Lymph nodes & $0.02 \pm 0.003$ & $0.06 \pm 0.01 \#$ \\
Bone marrow & $0.49 \pm 0.06$ & $0.47 \pm 0.09$ \\
Bone & $1.62 \pm 0.26$ & $2.20 \pm 0.45$ \\
Skin & $1.13 \pm 0.14$ & $1.77 \pm 0.29$ \\
Brain & $0.03 \pm 0.002$ & $0.04 \pm 0.005$ \\
Skeletal muscle & $2.45 \pm 0.36^{*}$ & $0.20 \pm 0.03$ \\
Testes & $0.14 \pm 0.01$ & $0.19 \pm 0.03$ \\
Kidneys & $0.08 \pm 0.01$ & $0.09 \pm 0.01$ \\
Spleen & $0.02 \pm 0.004$ & $0.02 \pm 0.004$ \\
Heart & $0.03 \pm 0.003$ & $0.02 \pm 0.004$ \\
Liver & $0.58 \pm 0.07$ & $0.71 \pm 0.09$ \\
Stomach & $0.07 \pm 0.01$ & $0.09 \pm 0.01$ \\
Small intestine & $0.25 \pm 0.03$ & $0.36 \pm 0.05$ \\
Large intestine & $0.09 \pm 0.02$ & $0.11 \pm 0.01$ \\
Cecum & $0.13 \pm 0.02$ & $0.12 \pm 0.02$ \\
Total recovered & $100.59 \pm 2.56^{*}$ & $83.40 \pm 2.42$ \\
\hline Dat are mean $\pm S E \%$ &
\end{tabular}

Data are mean \pm SE $\%$ gavaged dose, $n=5 /$ group.

Total recovered $=$ sum of ${ }^{65} \mathrm{Zn}$ in analyzed organs, feces and urine. ${ }^{*} \mathrm{P}<0.05, \mathrm{ZnO}>\mathrm{SiO}_{2}$-coated $\mathrm{ZnO}$.

\# $\mathrm{P}<0.05, \mathrm{SiO}_{2}$-coated $\mathrm{ZnO}>\mathrm{ZnO}$.

toxicity [36]. Since the $\mathrm{SiO}_{2}$ coating does not affect the core $\mathrm{ZnO}$ NP optoelectronic properties, these coatings may be employed in sunscreens and UV filters. This could be a strategy to reduce $\mathrm{ZnO}$ toxicity while maintaining the intended performance of $\mathrm{ZnO}$ NPs.

Intratracheal instillation differs from inhalation exposure in terms of particle distribution, dose rate, clearance, $\mathrm{NP}$ agglomerate surface properties, and pattern of injury $[44,45]$. A study by Baisch et al. reported a higher inflammatory response following intratracheal instillation compared to whole body inhalation for single and repeated exposures of titanium dioxide NPs when deposited doses were held constant [46]. Although IT instillation does not directly model inhalation exposure, it is a reliable method for administering a precise dose to the lungs for biokinetic studies. We hypothesized that silica coating may alter zinc-induced lung injury and inflammation by reducing the available zinc ions based on our previous data [17]. We have also shown that pulmonary toxicity in rats exposed to nanoceria via inhalation was reduced when exposed to the same nanoceria with amorphous $\mathrm{SiO}_{2}$ coating. Surprisingly, the in vivo lung responses in the present study showed the opposite. That amorphous silica can cause injury and inflammation when inhaled at high doses has been shown in several previous studies 

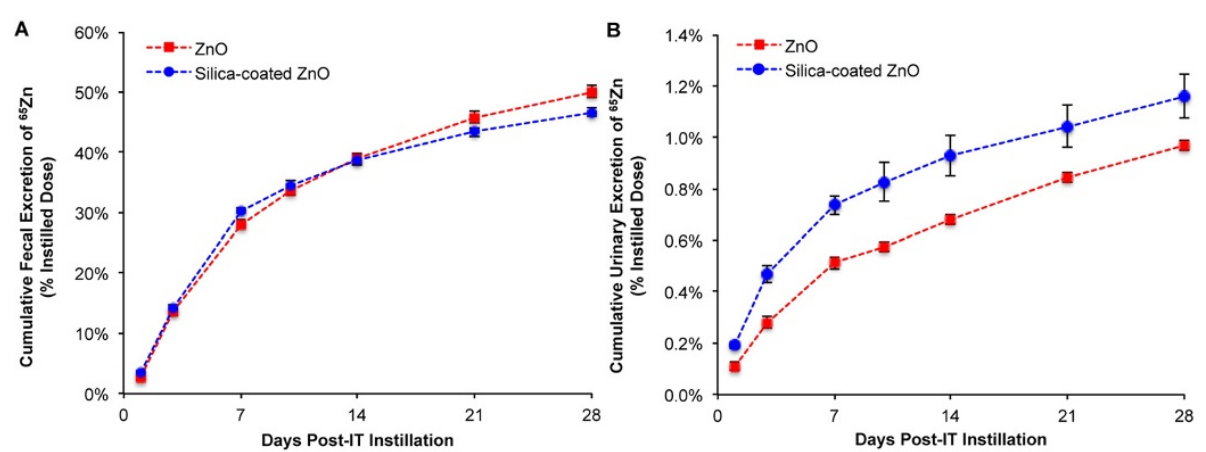

Figure $5 \mathrm{Fecal}$ and urinary excretion of ${ }^{65} \mathrm{Zn}$ post-IT instillation of ${ }^{65} \mathrm{ZnO}$ and $\mathrm{SiO}_{2}$-coated ${ }^{65} \mathrm{ZnO}$ NPs. Data are estimated cumulative urinary or fecal excretion of ${ }^{65} \mathrm{Zn}$ over 28 days. The predominant excretion pathway was via the feces. Approximately half of the instilled ${ }^{65} \mathrm{Zn}$ was excreted in the feces in both groups over 28 days (A). Only about $1 \%$ of the ${ }^{65} \mathrm{Zn}$ dose was excreted in the urine (B).

[47-51]. However, it has also been shown that the lung injury and inflammatory responses to amorphous silica are transient [27]. In this study, $\mathrm{SiO}_{2}$-coated $\mathrm{ZnO} \mathrm{NPs}$ induce more lung injury/inflammation than uncoated $\mathrm{ZnO}$, even at a low dose at which uncoated $\mathrm{ZnO}$ had no effects. Considering that the effective density of $\mathrm{ZnO}$ NPs is reduced by silica coating ( $\mathrm{ZnO}: 5.6 \mathrm{~g} / \mathrm{cm}^{3}$ vs. $\mathrm{SiO}_{2}$-coated $\mathrm{ZnO}$ : estimated $4.1 \mathrm{~g} / \mathrm{cm}^{3}$ ), it is possible that the coated particle number concentration is higher for an equivalent mass of NP. It is also likely that the silica coating elicits more inflammation than the $\mathrm{ZnO}$ NPs. Silica may act in concert with dissolved $\mathrm{Zn}$ ions, causing more lung injury. Furthermore, surface coating with amorphous silica also changed the zeta-potential of $\mathrm{ZnO} N$ Ps from positive $(23.0 \pm 0.4$ $\mathrm{mV}$, uncoated $\mathrm{ZnO} N P s)$ to negative $(-16.2 \pm 1.2 \mathrm{mV}$, $\mathrm{SiO}_{2}$-coated $\left.\mathrm{ZnO} \mathrm{NPs}\right)$, decreasing the likelihood of agglomeration and sedimentation of $\mathrm{SiO}_{2}$-coated NP suspension in aqueous systems. The reduced NP agglomeration of the $\mathrm{SiO}_{2}$-coated $\mathrm{ZnO}$ NPs may increase the available NP surface area that may facilitate biointeractions with lung cells and thus induces a higher toxic/inflammatory response. It has also been reported that surface charge may influence the lung translocation rates of NPs [52]. For example, the adsorption of endogenous proteins like albumin to the surface of charged NPs increases their hydrodynamic diameter and alters their translocation rate [53]. It was also showed that NPs with zwitterionic cysteine and polar PEG ligands on the surface cause their rapid translocation to the mediastinal lymph nodes. Additionally, a higher surface charge density has been shown to cause an increased adsorption of proteins on NPs [54] while zwitterionic or neutral organic coatings have been shown to prevent adsorption of serum proteins [18]. A recent study also showed that nanoparticle protein corona can alter their uptake by macrophages [55].

Our results demonstrate that $\mathrm{ZnO}$ and $\mathrm{SiO}_{2}$-coated $\mathrm{ZnO}$ NPs are both cleared rapidly and completely from the lungs by 28 days after IT instillation. In the lungs, NPs may be cleared via different pathways. They may be cleared by dissolution before or after alveolar macrophage uptake, by phagocytic cells in the lymph nodes, or
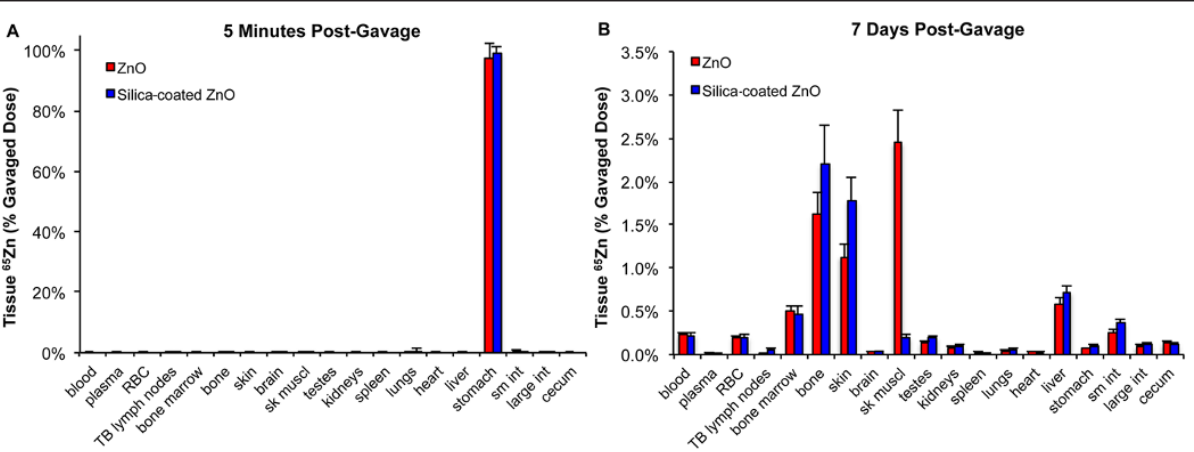

Figure 6 Tissue distribution of ${ }^{65} \mathrm{Zn}$ post-gavage of ${ }^{65} \mathrm{ZnO}$ and $\mathrm{SiO}_{2}$-coated ${ }^{65} \mathrm{ZnO} \mathrm{NPs}$. Data are $\%$ dose of administered ${ }^{65} \mathrm{Zn}$ in different organs. (A) At 5 minutes post-gavage, the ${ }^{65} \mathrm{Zn}$ levels in tissues other than the gastrointestinal tract were much lower $(0.3 \%$ for uncoated, $0.05 \%$ for coated ${ }^{65} \mathrm{ZnO} N \mathrm{NP}$ ). (B) At day 7, significantly more ${ }^{65} \mathrm{Zn}$ was absorbed and retained in non-GIT tissues (6.9\% for uncoated, $6.0 \%$ for coated ${ }^{65} \mathrm{ZnO}$ NPs). Significantly more ${ }^{65} \mathrm{Zn}$ was measured in skeletal muscle in rat gavaged with uncoated versus coated ${ }^{65} \mathrm{ZnO}$ NPs. (Note: RBC: red blood cell; sk muscl: skeletal muscle; sm int: small intestine: large int: large intestine). 

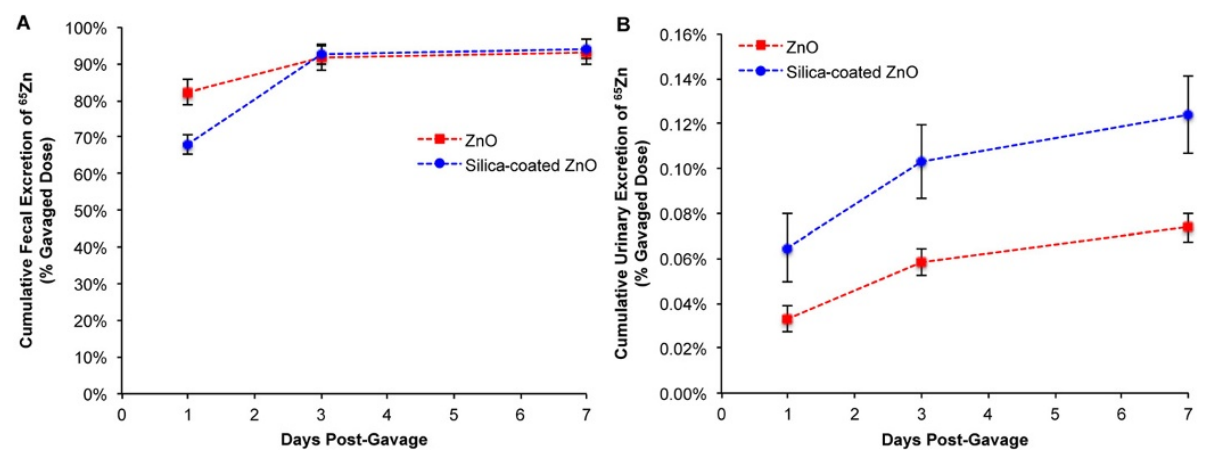

Figure $7 \mathrm{Fecal}$ and urinary excretion of ${ }^{65} \mathrm{Zn}$ post-gavage of ${ }^{65} \mathrm{ZnO}$ and $\mathrm{SiO}_{2}$-coated ${ }^{65} \mathrm{ZnO}$ NPs. Data are estimated cumulative urinary or fecal excretion of ${ }^{65} \mathrm{Zn}$ over 7 days. Similar to the IT-instilled groups, the predominant excretion pathway was via the feces. Ninety five $\%$ of the instilled ${ }^{65} \mathrm{Zn}$ was excreted in both groups by day 7 (A). Only $0.1 \%$ of the ${ }^{65} \mathrm{Zn}$ dose was excreted in the urine (B).

by translocation across the alveolar epithelium into the blood circulation [56]. Since ZnO NPs have been shown to dissolve in culture medium and in endosomes [57], it is not surprising that lung clearance of ${ }^{65} \mathrm{ZnO}$ NPs was rapid compared to that of poorly soluble NPs of cerium oxide [58] and titanium dioxide [59]. The clearance of radioactive ${ }^{65} \mathrm{Zn}$ from the lungs includes translocation of the NPs themselves as well as dissolution of ${ }^{65} \mathrm{ZnO}$ which is an important clearance mechanism [60]. As shown previously, the silica coating reduced the dissolution of $\mathrm{ZnO}$ NPs in culture medium [17], suggesting that dissolution and clearance in vivo may also be reduced. However, the silica coating appeared to very modestly but significantly enhance the amount of cleared ${ }^{65} \mathrm{Zn}$ at day 7 and 28. The significance of this observation needs further investigation.

Despite similar clearance from the lungs over 28 days, translocation of ${ }^{65} \mathrm{Zn}$ from uncoated ZnO NPs is significantly higher than from coated ZnO NPs in some of the examined extrapulmonary tissues, especially skeletal muscle. In these extrapulmonary tissues, the measured ${ }^{65} \mathrm{Zn}$ is more likely to be dissolved $\mathrm{Zn}$, rather than intact ${ }^{65} \mathrm{ZnO}$. The amount of ${ }^{65} \mathrm{Zn}$ was greatest in the skeletal muscle, liver, skin, and bone from both particle types. The selective retention of ${ }^{65} \mathrm{Zn}$ into those tissues might be explained, in part, by the fact that $85 \%$ of the total body zinc is present in skeletal muscle and bone [61]. There was clearance of ${ }^{65} \mathrm{Zn}$ from most of the extrapulmonary tissues we examined over time (day 2 to day 28), except in bone where ${ }^{65} \mathrm{Zn}$ levels increased. The skin and skeletal muscle exhibited faster clearance with coated than with uncoated NPs. ${ }^{65} \mathrm{Zn}$ from both particle types was largely excreted in the feces, presumably via pancreatobiliary secretion, and to a lesser extent via mucociliary clearance of instilled NPs [62]. A study investigating the pharmacokinetic behavior of inhaled iridium NPs showed that they accumulated in soft connective tissue (2\%) and bone, including bone marrow (5\%) [63].
Although this study indicates that the $\mathrm{SiO}_{2}$ coating modestly reduces the translocation of ${ }^{65} \mathrm{Zn}$ to the blood, skin, kidneys, heart, liver and skeletal muscle, it is unclear whether the $\mathrm{SiO}_{2}$-coated $\mathrm{ZnO} \mathrm{NPs}$ dissolve at a different rate in vivo, and whether ${ }^{65} \mathrm{Zn}$ is in particulate or ionic form when it reaches the circulation and bone. $\mathrm{ZnO}$ NPs have been shown to rapidly dissolve under acidic conditions ( $\mathrm{pH} 4.5$ ) and are more likely to remain intact around neutral pHs [64]. It is likely that the $\mathrm{ZnO}$ NPs entering phagolysosomal compartments of alveolar macrophages or neutrophils may encounter conditions favorable for dissolution. Our previous study suggested that the $\mathrm{SiO}_{2}$ coating is stable in vitro and exhibits low dissolution in biological media ( $<8 \%$ over 24 hours) [17]. Thus, it is possible that the $\mathrm{SiO}_{2}$-coated NPs remain in particulate form for a longer period of time. There are data showing that translocation of gold, silver, $\mathrm{TiO}_{2}$, polystyrene and carbon particles in the size range of 5-100 $\mathrm{nm}$ crossing the air-blood barrier and reaching blood circulation and extrapulmonary organs can occur [65-71].

The $\mathrm{SiO}_{2}$ coating significantly increased the levels of ${ }^{65} \mathrm{Zn}$ in the bone and bone marrow (Table 3). We note that zinc is essential to the development and maintenance of bone. Zinc is known to play a major role in bone growth in mammals [72], and is required for protein synthesis in osteoblasts [73]. It can also inhibit the development of osteoclasts from bone marrow cells, thereby reducing bone resorption and bone growth [74,75]. Radioactive ${ }^{65} \mathrm{Zn}$ from uncoated and coated ${ }^{65} \mathrm{ZnO}$ NPs also translocated to the skin, skeletal muscle, liver, heart, small intestine, testes, and brain (but to a lesser extent than the bone and bone marrow). It is important to note that of the 16 extrapulmonary tissues examined at 28 days after IT instillation, 4 had a higher ${ }^{65} \mathrm{Zn}$ content from uncoated $\mathrm{ZnO}$ than coated $\mathrm{ZnO}$ (blood, skin, skeletal muscle and heart) (Table 3). This suggests that amorphous silica coating of NPs may reduce $\mathrm{Zn}$ retention and its potential 
toxicity when accumulated at high levels in those organs. Whether coating modifications like the use of thicker or different coatings can further reduce $\mathrm{Zn}$ bioavailability warrants further investigation. There was significantly more ${ }^{65} \mathrm{Zn}$ from $\mathrm{SiO}_{2}$-coated $\mathrm{ZnO}$ excreted in the urine, which was more likely the ionic form of $\mathrm{Zn}$.

The oral exposure to ZnO NPs is relevant from an environmental health perspective. $\mathrm{ZnO}$ is widely used as a nutritional supplement and as a food additive [76]. Because it is an essential trace element, zinc is routinely added to animal food products and fertilizer [75]. Due to its antimicrobial properties, there is increasing interest in adding $\mathrm{ZnO}$ to polymers in food packaging and preservative films to prevent bacterial growth [77]. It is possible that $\mathrm{ZnO}$ in sunscreens, ointments, and other cosmetics can be accidentally ingested, especially by children. The biokinetic behavior of NPs in the gastrointestinal tract may be influenced by particle surface charge. Positively charged particles are attracted to negatively charged mucus, while negatively charged particles directly contact epithelial cell surfaces [78]. A study by Paek et al. investigating the effect of surface charge on the biokinetics of $\mathrm{Zn}$ over 4 hours after oral administration of ZnO NPs showed that negatively charged NPs were absorbed more than positively charged $\mathrm{ZnO}$ NPs [79]. However, no effect on tissue distribution was observed. This is in contrast to our findings at 7 days postgavage when coating of $\mathrm{ZnO}$ NPs with amorphous $\mathrm{SiO}_{2}$ (with negative zeta potential) increased the retention in thoracic lymph nodes compared to uncoated ZnO NPs (with positive zeta potential). Our study also showed that low levels of ${ }^{65} \mathrm{Zn}$ were retained in the blood, skeletal muscle, bone and skin from both coated and uncoated ${ }^{65} \mathrm{ZnO}$ NPs (Table 4). Most of the gavaged dose (over $90 \%$ ) was excreted in the feces by day 3 indicating a rapid clearance of $\mathrm{ZnO}$ NPs, consistent with previous reports. Another study reported the pharmacokinetics of $\mathrm{ZnO}$ NPs $(125,250$ and $500 \mathrm{mg} / \mathrm{kg})$ after a single and repeated dose oral administration (90-day) [80]. They found that plasma $\mathrm{Zn}$ concentration significantly increased in a dose-dependent manner, but significantly decreased within 24 hours post-oral administration, suggesting that the systemic clearance of $\mathrm{ZnO}$ NPs is rapid even at these high doses. In another study, Baek et al. examined the pharmacokinetics of $20 \mathrm{~nm}$ and $70 \mathrm{~nm}$ citrate-modified $\mathrm{ZnO} \mathrm{NPs}$ at doses of 50, 300 and $2000 \mathrm{mg} / \mathrm{kg}$ [81]. Similar to our results, they showed that $\mathrm{ZnO}$ NPs were not readily absorbed into the bloodstream after single-dose oral administration. The tissue distributions of $\mathrm{Zn}$ from both $20 \mathrm{~nm}$ and $70 \mathrm{~nm} \mathrm{ZnO}$ NPs were similar and mainly to the liver, lung and kidneys. The study also reported predominant excretion of $\mathrm{Zn}$ in the feces, with smaller $20 \mathrm{~nm}$ particles being cleared more rapidly than the $70 \mathrm{~nm}$ NPs.
In summary, the results presented here show that uncoated ${ }^{65} \mathrm{Zn}$ NPs resulted in higher levels of ${ }^{65} \mathrm{Zn}$ in multiple organs following intratracheal instillation or gavage, particularly in skeletal muscle. This suggests that coating with amorphous silica can reduce tissue $\mathrm{Zn}$ concentration and its potential toxicity. Interestingly, the bioavailability of $\mathrm{Zn}$ from $\mathrm{SiO}_{2}$-coated ${ }^{65} \mathrm{ZnO}$ was higher in thoracic lymph nodes and bone. Additionally, the excretion of ${ }^{65} \mathrm{Zn}$ was higher from $\mathrm{SiO}_{2}$-coated ${ }^{65} \mathrm{ZnO}$ NPs from both routes suggesting enhanced hepatobiliary excretion. Our data indicate that silica coating alters the pharmacokinetic behavior of $\mathrm{ZnO}$ NPs, but the effect was not as dramatic as anticipated. With increasing trends in physicochemical modifications of NPs for special applications, it is necessary to understand their influence on the fate, metabolism and toxicity of these nanoparticles.

\section{Conclusions}

We examined the influence of a $4.5 \mathrm{~nm} \mathrm{SiO} 2$ coating on $\mathrm{ZnO}$ NPs on the ${ }^{65} \mathrm{Zn}$ pharmacokinetics following IT instillation and gavage of neutron activated NPs. The $\mathrm{SiO}_{2}$ coating does not affect the clearance of ${ }^{65} \mathrm{Zn}$ from the lungs. However, the extrapulmonary translocation and distribution of ${ }^{65} \mathrm{Zn}$ from coated versus uncoated ${ }^{65} \mathrm{ZnO}$ NPs were significantly altered in some tissues. The $\mathrm{SiO}_{2}$ coating resulted in lower translocation of instilled ${ }^{65} \mathrm{Zn}$ to the skeletal muscle, skin and heart. The $\mathrm{SiO}_{2}$ coating also reduced ${ }^{65} \mathrm{Zn}$ translocation to skeletal muscle postgavage. For both routes of administration, the $\mathrm{SiO}_{2}$ coating enhanced the transport of ${ }^{65} \mathrm{Zn}$ to the thoracic lymph nodes.

\section{Methods}

\section{Synthesis of $\mathrm{ZnO}$ and $\mathrm{SiO}_{2}$-coated $\mathrm{ZnO}$ NPs}

The synthesis of these NPs was reported in detail elsewhere [17]. In brief, uncoated and $\mathrm{SiO}_{2}$-coated $\mathrm{ZnO}$ particles were synthesized by flame spray pyrolysis (FSP) of zinc naphthenate (Sigma-Aldrich, St. Louis, MO, USA) dissolved in ethanol (Sigma-Aldrich) at a precursor molarity of $0.5 \mathrm{M}$. The precursor solution was fed through a stainless steel capillary at $5 \mathrm{ml} / \mathrm{min}$, dispersed by $5 \mathrm{~L} / \mathrm{min}$ $\mathrm{O}_{2}$ (purity $>99 \%$, pressure drop at nozzle tip: $\mathrm{p}_{\mathrm{drop}}=$ 2 bar) (Air Gas, Berwyn, PA, USA) and combusted. A premixed methane-oxygen $(1.5 \mathrm{~L} / \mathrm{min}, 3.2 \mathrm{~L} / \mathrm{min})$ supporting flame was used to ignite the spray. Oxygen (Air Gas, purity $>99 \%$ ) sheath gas was used at $40 \mathrm{~L} / \mathrm{min}$. Core particles were coated in-flight by the swirl-injection of hexamethyldisiloxane (HMDSO) (Sigma Aldrich) through a torus ring with 16 jets at an injection height of $200 \mathrm{~mm}$ above the FSP burner. A total gas flow of $16 \mathrm{~L} / \mathrm{min}$, consisting of $\mathrm{N}_{2}$ carrying HMDSO vapor and pure $\mathrm{N}_{2}$, was injected through the torus ring jets. HMDSO vapor was obtained by bubbling $\mathrm{N}_{2}$ gas through liquid HMDSO 
$(500 \mathrm{ml})$, maintained at a controlled temperature using a temperature-controlled water bath.

\section{Characterization of $\mathrm{ZnO}$ and $\mathrm{SiO}_{2}$-coated $\mathrm{ZnO}$ NPs}

The morphology of these NPs was examined by electron microscopy. Uncoated and $\mathrm{SiO}_{2}$-coated $\mathrm{ZnO}$ NPs were dispersed in ethanol at a concentration of $1 \mathrm{mg} / \mathrm{ml}$ in $50 \mathrm{ml}$ polyethylene conical tubes and sonicated at $246 \mathrm{~J} / \mathrm{ml}$ (Branson Sonifier S-450A, Swedesboro, NJ, USA). The samples were deposited onto lacey carbon TEM grids. All grids were imaged with a JEOL 2100. The primary particle size was determined by X-ray diffraction (XRD). XRD patterns for uncoated $\mathrm{ZnO}$ and $\mathrm{SiO}_{2}$-coated $\mathrm{ZnO}$ NPs were obtained using a Scintag XDS2000 powder diffractometer $(\mathrm{Cu} \mathrm{K} \alpha, \lambda=0.154 \mathrm{~nm}, 40 \mathrm{kV}, 40 \mathrm{~mA}$, stepsize $=0.02^{\circ}$. One hundred $\mathrm{mg}$ of each sample was placed onto the diffractometer stage and analyzed from a range of $2 \theta=20-70^{\circ}$. Major diffraction peaks were identified using the Inorganic Crystal Structure Database (ICSD) for wurtzite $(\mathrm{ZnO})$ crystals. The crystal size was determined by applying the Debye-Scherrer Shape Equation to the Gaussian fit of the major diffraction peak. The specific surface area was obtained using the Brunauer-Emmet-Teller (BET) method. The samples were degassed in $\mathrm{N}_{2}$ for at least 1 hour at $150^{\circ} \mathrm{C}$ before obtaining five-point $\mathrm{N}_{2}$ adsorption at $77 \mathrm{~K}$ (Micrometrics Tristar 3000, Norcross, GA, USA).

\section{Neutron activation of NPs}

The NPs with and without the $\mathrm{SiO}_{2}$ coating were neutronactivated at the Massachusetts Institute of Technology (MIT) Nuclear Reactor Laboratory (Cambridge, MA). Samples were irradiated with a thermal neutron flux of $5 \times 10^{13} \mathrm{n} / \mathrm{cm}^{2} \mathrm{~s}$ for 120 hours. The resulting ${ }^{65} \mathrm{Zn}$ radioisotope has a half-life of 244.3 days and a primary gamma energy peak of $1115 \mathrm{keV}$. The relative specific activities for ${ }^{65} \mathrm{Zn}$ were $37.7 \pm 5.0 \mathrm{kBq} / \mathrm{mg}$ for $\mathrm{SiO}_{2}$ coated ${ }^{65} \mathrm{ZnO}$ and $41.7 \pm 7.2 \mathrm{kBq} / \mathrm{mg}$ for ${ }^{65} \mathrm{ZnO}$ NPs.

\section{Preparation and characterization of $\mathrm{ZnO}$ and $\mathrm{SiO}_{2}$-coated ZnO nanoparticle suspensions}

Uncoated and $\mathrm{SiO}_{2}$-coated $\mathrm{ZnO}$ NPs were dispersed using a protocol previously described $[82,36]$. The NPs were dispersed in deionized water at a concentration of $0.66 \mathrm{mg} / \mathrm{ml}$ (IT) or $10 \mathrm{mg} / \mathrm{ml}$ (gavage). Sonication was performed in deionized water to minimize the formation of reactive oxygen species. Samples were thoroughly mixed immediately prior to instillation. Dispersions of NPs were analyzed for hydrodynamic diameter $\left(d_{H}\right)$, polydispersity index (PdI), and zeta potential $(\zeta)$ by DLS using a Zetasizer Nano-ZS (Malvern Instruments, Worcestershire, UK).

\section{Animals}

The protocols used in this study were approved by the Harvard Medical Area Animal Care and Use Committee. Nine-week-old male Wistar Han rats were purchased from Charles River Laboratories (Wilmington, MA). Rats were housed in pairs in polypropylene cages and allowed to acclimate for 1 week before the studies were initiated. Rats were maintained on a 12-hour light/dark cycle. Food and water were provided ad libitum.

\section{Pulmonary responses - Bronchoalveolar lavage and analyses}

This experiment was performed to determine pulmonary responses to instilled NPs. A group of rats (mean wt. $264 \pm$ $15 \mathrm{~g}$ ) was intratracheally instilled with either an uncoated $\mathrm{ZnO}$ or $\mathrm{SiO}_{2}$-coated $\mathrm{ZnO} \mathrm{NP}$ suspension at a $0,0.2$ or $1.0 \mathrm{mg} / \mathrm{kg}$ dose. The particle suspensions were delivered to the lungs through the trachea in a volume of $1.5 \mathrm{ml} / \mathrm{kg}$. Twenty-four hours later, rats were euthanized via exsanguination with a cut in the abdominal aorta while under anesthesia. The trachea was exposed and cannulated. The lungs were then lavaged 12 times, with $3 \mathrm{ml}$ of $0.9 \%$ sterile PBS, without calcium and magnesium ions. The cells of all washes were separated from the supernatant by centrifugation $\left(350 \times \mathrm{g}\right.$ at $4^{\circ} \mathrm{C}$ for $\left.10 \mathrm{~min}\right)$. Total cell count and hemoglobin measurements were made from the cell pellets. After staining the cells, a differential cell count was performed. The supernatant of the two first washes was clarified via centrifugation $\left(14,500 \times \mathrm{g}\right.$ at $4^{\circ} \mathrm{C}$ for $\left.30 \mathrm{~min}\right)$, and used for standard spectrophotometric assays for lactate dehydrogenase (LDH), myeloperoxidase (MPO) and albumin.

\section{Pharmacokinetics of ${ }^{65} \mathrm{Zn}$}

The mean weight of rats at the start of the experiment was $285 \pm 3$ g. Two groups of rats (29 rats/NP) were intratracheally instilled with ${ }^{65} \mathrm{ZnO} \mathrm{NPs}$ or with $\mathrm{SiO}_{2}$ coated ${ }^{65} \mathrm{ZnO} \mathrm{NPs}$ at a $1 \mathrm{mg} / \mathrm{kg}$ dose $(1.5 \mathrm{ml} / \mathrm{kg}$, $0.66 \mathrm{mg} / \mathrm{ml}$ ). Rats were placed in metabolic cages containing food and water, as previously described. Twenty four-hour samples of feces and urine were collected at selected time points (0-24 hours, 2-3 days, 6-7 days, 9-10 days, 13-14 days, 20-21 days, and 27-28 days post-IT instillation). Fecal/urine collection was accomplished by placing each rat in individual metabolic cage containing food and water during each 24-hour period. All samples were analyzed for total ${ }^{65} \mathrm{Zn}$ activity, and expressed as $\%$ of instilled ${ }^{65} \mathrm{Zn}$ dose. Fecal and urine clearance curves were generated and were used to estimate the daily cumulative excretion. Groups of 8 rats were humanely sacrificed at 5 minutes, 2 days, 7 days, and 5 rats/group at 28 days. Therefore, the number of collected fecal/urine samples decreased over time.

Another cohort of 20 rats was dosed with ${ }^{65} \mathrm{ZnO}(\mathrm{n}=10)$ or $\mathrm{SiO}_{2}$-coated ${ }^{65} \mathrm{ZnO}(\mathrm{n}=10)$ by gavage at a $5 \mathrm{mg} / \mathrm{kg}$ dose 
$(0.5 \mathrm{ml} / \mathrm{kg}, 10 \mathrm{mg} / \mathrm{ml})$. One group of 5 rats was humanely sacrificed at 5 minutes and immediately dissected. Another group of 5 rats was individually placed in metabolic cages, as previously described, and 24-hour samples of urine and feces were collected at 0-1 day, 2-3 days, and 6-7 days post-gavage. The remaining rats were sacrificed at 7 days.

At each endpoint, rats were euthanized and dissected, and the whole brain, spleen, kidneys, heart, liver, lungs, GI tract, testes, thoracic lymph nodes, blood $(10 \mathrm{ml}$, separated into plasma and RBC), bone marrow (from femoral bones), bone (both femurs), skin $(2 \times 3$ inches), and skeletal muscle (from 4 sites) were collected. The ${ }^{65} \mathrm{Zn}$ radioactivity present in each sample was measured with a WIZARD Gamma Counter (PerkinElmer, Inc., Waltham, MA). The number of disintegrations per minute was determined from the counts per minute and the counting efficiency. The efficiency of the gamma counter was derived from counting multiple aliquots of NP samples and relating them to the specific activities measured at Massachusetts Institute of Technology Nuclear Reactor. We estimated that the counter had an efficiency of $\sim 52 \%$. The ${ }^{65} \mathrm{Zn}$ radioactivity was expressed as $\mathrm{kBq} / \mathrm{g}$ tissue and the percentage of administered dose in each organ. All radioactivity data were adjusted for physical decay over the entire observation period. The radioactivity in organs and tissues not measured in their entirety was estimated as a percentage of total body weight as: skeletal muscle, 40\%; bone marrow, 3.2\%; peripheral blood, 7\%; skin, 19\%; and bone, $6 \%[83,84]$. Based on the ${ }^{65} \mathrm{Zn}$ specific activity $(\mathrm{kBq} / \mathrm{mg} \mathrm{NP})$ and tissue ${ }^{65} \mathrm{Zn}$ concentration, the amount of $\mathrm{Zn}$ derived from each NP was calculated for each tissue examined (ng Zn/g tissue).

\section{Statistical analyses}

Differences in the ${ }^{65} \mathrm{Zn}$ tissue distribution and in cellular and biochemical parameters measured in bronchoalveolar lavage between groups were analyzed using multivariate analysis of variance (MANOVA) with REGWQ (Ryan-Einot-Gabriel-Welch based on range) and Tukey post hoc tests using SAS Statistical Analysis software (SAS Institute, Cary, NC). The lung clearance half-life was estimated by a two-phase estimation by a biexponential model using the R Program v. 3.1.0 [85].

\section{Competing interests}

The authors declare that they have no competing interests.

\section{Authors' contributions \\ NVK, KMM, RMM, and JDB designed and performed the lung toxicity and pharmacokinetic studies. TCD performed statistical analyses. PD and GAS synthesized and characterized the NPs. This manuscript was written by NVK, RMM, and KMM and revised by JDB, GS, PD and RMM. All authors read, corrected and approved the manuscript.}

\section{Acknowledgements}

This research was supported by NSF (1235806) and NIEHS grant (ES 0000002). GAS was supported by the Swiss National Science foundation for the Advanced
Researcher fellowship (grant no. 145392). KMM received a Graduate Research Fellowship from the National Science Foundation (DGE-1144152). We thank Dr Evelyn Hu (Harvard School of Engineering and Applied Sciences) for helpful discussions and Melissa Curran for editorial assistance.

Received: 15 April 2014 Accepted: 20 August 2014 Published: 3 September 2014

\section{References}

1. Sun B, Sirringhaus $H$ : Solution-processed zinc oxide field-effect transistors based on self-assembly of colloidal nanorods. Nano Lett 2005, 5:2408-2413.

2. Su YK, Peng SM, Ji LW, Wu CZ, Cheng WB, Liu CH: Ultraviolet ZnO nanorod photosensors. Langmuir 2010, 26:603-606.

3. Djurisic $A B$, Leung $\mathrm{YH}$ : Optical properties of $\mathrm{ZnO}$ nanostructures. Small 2006, 2:944-961.

4. Nohynek GJ, Dufour EK, Roberts MS: Nanotechnology, cosmetics and the skin: is there a health risk? Skin Pharmacol Physiol 2008, 21:136-149.

5. Fan Z, Lu JG: Zinc oxide nanostructures: synthesis and properties. J Nanosci Nanotechnol 2005, 5:1561-1573.

6. Beckett WS, Chalupa DF, Pauly-Brown A, Speers DM, Stewart JC, Frampton MW, Utell MJ, Huang LS, Cox C, Zareba W, Oberdorster G: Comparing inhaled ultrafine versus fine zinc oxide particles in healthy adults: a human inhalation study. Am J Respir Crit Care Med 2005, 171:1129-1135.

7. Sharma V, Anderson D, Dhawan A: Zinc oxide nanoparticles induce oxidative stress and genotoxicity in human liver cells (HepG2). J Biomed Nanotechnol 2011, 7:98-99.

8. Valdiglesias V, Costa C, Kilic G, Costa S, Pasaro E, Laffon B, Teixeira JP: Neuronal cytotoxicity and genotoxicity induced by zinc oxide nanoparticles. Environ Int 2013, 55:92-100.

9. Alarifi S, Ali D, Alkahtani S, Verma A, Ahamed M, Ahmed M, Alhadlaq HA Induction of oxidative stress, DNA damage, and apoptosis in a malignant human skin melanoma cell line after exposure to zinc oxide nanoparticles. Int J Nanomed 2013, 8:983-993.

10. Watson C, Ge J, Cohen J, Pyrgiotakis G, Engelward BP, Demokritou P: Highthroughput screening platform for engineered nanoparticle-mediated genotoxicity using CometChip technology. ACS Nano 2014, 8:2118-2133.

11. De Berardis B, Civitelli G, Condello M, Lista P, Pozzi R, Arancia G, Meschini S: Exposure to $\mathrm{ZnO}$ nanoparticles induces oxidative stress and cytotoxicity in human colon carcinoma cells. Toxicol Appl Pharmacol 2010, 246:116-127.

12. Vandebriel RJ, De Jong WH: A review of mammalian toxicity of $\mathrm{ZnO}$ nanoparticles. Nanotechnol Sci Appl 2012, 5:61-71.

13. Warheit DB, Sayes CM, Reed KL: Nanoscale and fine zinc oxide particles: can in vitro assays accurately forecast lung hazards following inhalation exposures? Environ Sci Technol 2009, 43:7939-7945.

14. Moghimi SM, Davis SS: Innovations in avoiding particle clearance from blood by Kupffer cells: cause for reflection. Crit Rev Ther Drug Carrier Syst 1994, 11:31-59.

15. Sund J, Alenius H, Vippola M, Savolainen K, Puustinen A: Proteomic characterization of engineered nanomaterial-protein interactions in relation to surface reactivity. ACS Nano 2011, 5:4300-4309.

16. Xia T, Zhao Y, Sager T, George S, Pokhrel S, Li N, Schoenfeld D, Meng H, Lin S, Wang X, Wang M, Ji Z, Zink Jl, Madler L, Castranova V, Nel AE: Decreased dissolution of $\mathrm{ZnO}$ by iron doping yields nanoparticles with reduced toxicity in the rodent lung and zebrafish embryos. ACS Nano 2011, 5:1223-1235.

17. Sotiriou GA, Watson C, Murdaugh KM, Darrah TH, Pyrgiotakis G, Elder A, Brain JD, Demokritou P: Engineering safer-by-design, transparent, silica-coated $\mathrm{ZnO}$ nanorods with reduced DNA damage potential. Environ Sci Nano 2014, 1:144-153.

18. Choi HS, Liu W, Misra P, Tanaka E, Zimmer JP, Itty Ipe B, Bawendi MG, Frangioni JV: Renal clearance of quantum dots. Nat Biotechnol 2007, 25:1165-1170.

19. Lundqvist M, Stigler J, Elia G, Lynch I, Cedervall T, Dawson KA: Nanoparticle size and surface properties determine the protein corona with possible implications for biological impacts. Proc Natl Acad Sci U S A 2008, 105:14265-14270.

20. Moghimi SM, Hunter AC, Andresen TL: Factors controlling nanoparticle pharmacokinetics: an integrated analysis and perspective. Annu Rev Pharmacol Toxicol 2012, 52:481-503.

21. Lynch I, Salvati A, Dawson KA: Protein-nanoparticle interactions: what does the cell see? Nat Nanotechnol 2009, 4:546-547. 
22. Monopoli MP, Aberg C, Salvati A, Dawson KA: Biomolecular coronas provide the biological identity of nanosized materials. Nat Nanotechnol 2012, 7:779-786

23. Alwi R, Telenkov S, Mandelis A, Leshuk T, Gu F, Oladepo S, Michaelian K: Silica-coated super paramagnetic iron oxide nanoparticles (SPION) as biocompatible contrast agent in biomedical photoacoustics. Biomed Opt Express 2012, 3:2500-2509.

24. Jana NR, Yu HH, Ali EM, Zheng Y, Ying JY: Controlled photostability of luminescent nanocrystalline $\mathrm{ZnO}$ solution for selective detection of aldehydes. Chem Commun (Camb) 2007, 1406-1408.

25. Chen Y-S, Wolfgang F, Seungsoo K, Pieter K, Kimberly H, Stanislav E: Silicacoated gold nanorods as photoacoustic signal nano-amplifiers. Nano Lett 2011, 11:348-354.

26. Baber $\mathrm{O}$, Jang M, Barber D, Powers K: Amorphous silica coatings on magnetic nanoparticles enhance stability and reduce toxicity to in vitro BEAS-2B cells. Inhal Toxicol 2011, 23:532-543.

27. Moghimi SM, Hunter AC, Murray JC: Long-circulating and target-specific nanoparticles: theory to practice. Pharmacol Rev 2001, 53:283-318.

28. Brunner TJ, Wick P, Manser P, Spohn P, Grass RN, Limbach LK, Bruinink A Stark WJ: In vitro cytotoxicity of oxide nanoparticles: comparison to asbestos, silica, and the effect of particle solubility. Environ Sci Technol 2006, 40:4374-4381.

29. Napierska D, Thomassen LC, Rabolli V, Lison D, Gonzalez L, Kirsch-Volders M, Martens JA, Hoet PH: Size-dependent cytotoxicity of monodisperse silica nanoparticles in human endothelial cells. Small 2009, 5:846-853.

30. Warheit DB, McHugh TA, Hartsky MA: Differential pulmonary responses in rats inhaling crystalline, colloidal or amorphous silica dusts. Scand J Work Environ Health 1995, 21(Suppl 2):19-21.

31. Demokritou P, Gass S, Pyrgiotakis G, Cohen JM, Goldsmith W, McKinney W, Frazer D, Ma J, Schwegler-Berry D, Brain J, Castranova V: An in vivo and in vitro toxicological characterisation of realistic nanoscale $\mathrm{CeO}(2)$ inhalation exposures. Nanotoxicology 2013, 7:1338-1350.

32. Sotiriou GA, Sannomiya T, Teleki A, Krumeich F, Voros J, Pratsinis SE: Nontoxic dry-coated nanosilver for plasmonic biosensors. Adv Funct Mater 2010, 20:4250-4257.

33. Sotiriou GA, Franco D, Poulikakos D, Ferrari A: Optically stable biocompatible flame-made SiO2-coated Y2O3:Tb3+ nanophosphors for cell imaging. ACS Nano 2012, 6:3888-3897.

34. Teleki A, Heine MC, Krumeich F, Akhtar MK, Pratsinis SE: In situ coating of flame-made $\mathrm{TiO} 2$ particles with nanothin $\mathrm{SiO} 2$ films. Langmuir 2008, 24:12553-12558.

35. Demokritou P, Buchel R, Molina RM, Deloid GM, Brain JD, Pratsinis SE: Development and characterization of a Versatile Engineered Nanomaterial Generation System (VENGES) suitable for toxicological studies. Inhal Toxicol 2010, 22(Suppl 2):107-116.

36. Gass S, Cohen JM, Pyrgiotakis G, Sotiriou GA, Pratsinis SE, Demokritou P: A safer formulation concept for flame-generated engineered nanomaterials. ACS Sustain Chem Eng 2013, 1:843-857.

37. Hembram K, Sivaprakasam D, Rao TN, Wegner K: Large-scale manufacture of ZnO nanorods by flame spray pyrolysis. J Nanopart Res 2013, 15:1461-1464.

38. Beaucage G, Kammler HK, Pratsinis SE: Particle size distributions from small-angle scattering using global scattering functions. J App/ Crystallogr 2004, 37:523-535.

39. Height MJ, Madler L, Pratsinis SE: Nanorods of $\mathrm{ZnO}$ made by flame spray pyrolysis. Chem Mater 2006, 18:572-578.

40. Sotiriou GA, Schneider M, Pratsinis SE: Green, silica-coated monoclinic $\mathrm{Y}_{2} \mathrm{O}_{3}: \mathrm{Tb}^{3+}$ nanophosphors: flame synthesis and characterization. J Phys Chem C 2012, 116:4493-4499.

41. Buesser B, Pratsinis SE: Design of gas-phase synthesis of core-shell particles by computational fluid - aerosol dynamics. AlChE J 2011, 57:3132-3142.

42. Brouwer D: Exposure to manufactured nanoparticles in different workplaces. Toxicology 2010, 269:120-127.

43. Vorbau M, Hillemann L, Stintz M: Method for the characterization of the abrasion induced nanoparticle release into air from surface coatings. Aerosol Sci 2009, 40:209-217.

44. Brain JD, Knudson DE, Sorokin SP, Davis MA: Pulmonary distribution of particles given by intratracheal instillation or by aerosol inhalation. Environ Res 1976, 11:13-33.

45. Osier M, Oberdorster G: Intratracheal inhalation vs intratracheal instillation: differences in particle effects. Fundam Appl Toxicol 1997, 40:220-227.
46. Baisch BL, Corson NM, Wade-Mercer P, Gelein R, Kennell AJ, Oberdorster G, Elder A: Equivalent titanium dioxide nanoparticle deposition by intratracheal instillation and whole body inhalation: the effect of dose rate on acute respiratory tract inflammation. Part Fibre Toxicol 2014, 11:5.

47. Du Z, Zhao D, Jing L, Cui G, Jin M, Li Y, Liu X, Liu Y, Du H, Guo C, Zhou X, Sun Z: Cardiovascular toxicity of different sizes amorphous silica nanoparticles in rats after intratracheal instillation. Cardiovasc Toxicol 2013, 13:194-207.

48. Johnston CJ, Driscoll KE, Finkelstein JN, Baggs R, O'Reilly MA, Carter J, Gelein $\mathrm{R}$, Oberdorster G: Pulmonary chemokine and mutagenic responses in rats after subchronic inhalation of amorphous and crystalline silica. Toxicol Sci 2000, 56:405-413.

49. McCarthy J, Inkielewicz-Stepniak I, Corbalan JJ, Radomski MW: Mechanisms of toxicity of amorphous silica nanoparticles on human lung submucosal cells in vitro: protective effects of fisetin. Chem Res Toxicol 2012, 25:2227-2235.

50. Merget R, Bauer T, Kupper HU, Philippou S, Bauer HD, Breitstadt R, Bruening T: Health hazards due to the inhalation of amorphous silica. Arch Toxicol 2002, 75:625-634.

51. Warheit DB, Webb TR, Reed KL: Pulmonary toxicity screening studies in male rats with $\mathrm{TiO} 2$ particulates substantially encapsulated with pyrogenically deposited, amorphous silica. Part Fibre Toxicol 2006, 3:3.

52. Braakhuis HM, Park MV, Gosens I, De Jong WH, Cassee FR: Physicochemical characteristics of nanomaterials that affect pulmonary inflammation. Part Fibre Toxicol 2014, 11:18.

53. Choi HS, Ashitate $Y$, Lee JH, Kim SH, Matsui A, Insin N, Bawendi MG, Semmler-Behnke M, Frangioni JV, Tsuda A: Rapid translocation of nanoparticles from the lung airspaces to the body. Nat Biotechnol 2010, 28:1300-1303.

54. Gessner A, Lieske A, Paulke B, Muller R: Influence of surface charge density on protein adsorption on polymeric nanoparticles: analysis by twodimensional electrophoresis. Eur J Pharm Biopharm 2002, 54:165-170.

55. Lartigue L, Wilhelm C, Servais J, Factor C, Dencausse A, Bacri JC, Luciani N, Gazeau F: Nanomagnetic sensing of blood plasma protein interactions with iron oxide nanoparticles: impact on macrophage uptake. ACS Nano 2012, 6:2665-2678

56. Buzea C, Pacheco II, Robbie K: Nanomaterials and nanoparticles: sources and toxicity. Biointerphases 2007, 2:MR17-71

57. Xia T, Kovochich M, Liong M, Madler L, Gilbert B, Shi H, Yeh Jl, Zink Jl, Nel $A E$ : Comparison of the mechanism of toxicity of zinc oxide and cerium oxide nanoparticles based on dissolution and oxidative stress properties. ACS Nano 2008, 2:2121-2134

58. He X, Zhang H, Ma Y, Bai W, Zhang Z, Lu K, Ding Y, Zhao Y, Chai Z: Lung deposition and extrapulmonary translocation of nano-ceria after intratracheal instillation. Nanotechnology 2010, 21:285103.

59. Cullen RT, Tran CL, Buchanan D, Davis JM, Searl A, Jones AD, Donaldson K. Inhalation of poorly soluble particles. I. Differences in inflammatory response and clearance during exposure. Inhal Toxicol 2000 12:1089-1111.

60. Adamcakova-Dodd A, Stebounova LV, Kim JS, Vorrink SU, Ault AP, O'Shaughnessy PT, Grassian VH, Thorne PS: Toxicity assessment of zinc oxide nanoparticles using sub-acute and sub-chronic murine inhalation models. Part Fibre Toxicol 2014, 11:15

61. Council, N.R: Mineral Tolerance of Animals. 2nd edition. Washington. D.C: The National Academic Press; 2005.

62. WHO: Environmental Health Criteria 221 Zinc. Geneva: Worl Health Organization; 2001

63. Kreyling WG, Semmler-Behnke M, Seitz J, Scymczak W, Wenk A, Mayer P, Takenaka S, Oberdörster G: Size and material dependency of translocation of inhaled iridium or carbon nanoparticles from the lungs of rats to blood. Inhal Toxicol 2009, 21:55-60.

64. Cho WS, Duffin R, Howie SE, Scotton CJ, Wallace WA, Macnee W, Bradley M, Megson IL, Donaldson K: Progressive severe lung injury by zinc oxide nanoparticles; the role of $\mathrm{Zn} 2+$ dissolution inside lysosomes. Part Fibre Toxicol 2011, 8:27.

65. Berry JP, Arnoux B, Stanislas G, Galle P, Chretien J: A microanalytic study of particles transport across the alveoli: role of blood platelets. Biomedicine 1977, 27:354-357.

66. Cohen JM, Derk R, Wang L, Godleski J, Kobzik L, Brain J, Demokritou P: Tracking translocation of industrially relevant engineered nanomaterials (ENMs) across alveolar epithelial monolayers in vitro. Nanotoxicology 2014, 8:216-225. 
67. Geiser M, Kreyling WG: Deposition and biokinetics of inhaled nanoparticles. Part Fibre Toxicol 2010, 7:2.

68. Geiser M, Rothen-Rutishauser B, Kapp N, Schurch S, Kreyling W, Schulz H, Semmler M, Im Hof V, Heyder J, Gehr P: Ultrafine particles cross cellular membranes by nonphagocytic mechanisms in lungs and in cultured cells. Environ Health Perspect 2005, 113:1555-1560.

69. Oberdorster G, Sharp Z, Atudorei V, Elder A, Gelein R, Lunts A, Kreyling W, Cox C: Extrapulmonary translocation of ultrafine carbon particles following whole-body inhalation exposure of rats. J Toxicol Environ Health A 2002, 65:1531-1543.

70. Semmler M, Seitz J, Erbe F, Mayer P, Heyder J, Oberdorster G, Kreyling WG: Long-term clearance kinetics of inhaled ultrafine insoluble iridium particles from the rat lung, including transient translocation into secondary organs. Inhal Toxicol 2004, 16:453-459.

71. Takenaka S, Karg E, Roth C, Schulz H, Ziesenis A, Heinzmann U, Schramel P, Heyder J: Pulmonary and systemic distribution of inhaled ultrafine silver particles in rats. Environ Health Perspect 2001, 109(Suppl 4):547-551.

72. Burch RE, Hahn HK, Sullivan JF: Newer aspects of the roles of zinc, manganese, and copper in human nutrition. Clin Chem 1975, 21:501-520.

73. Seo J-H, Cho Y-E, Kim T, Shin H-I, Kwun I-S: Zinc may increase bone formation through stimulating cell proliferation, alkaline phosphatase activity and collagen synthesis in osteoblastic. Nutr Res Pract 2010, 4:356-361.

74. Hashizume M, Yamaguchi M: Stimulatory effect of beta-alanyl-L-histidinato zinc on cell proliferation is dependent on protein synthesis in osteoblastic MC3T3-E1 cells. Mol Cell Biochem 1993, 122:59-64.

75. Yamaguchi M, Igarashi A, Uchiyama S: Bioavailability of zinc yeast in rats: stimulatory effect of bone calcification in vivo. J Health Sci 2004, 50(1):75-81.

76. Hilty FM, Arnold M, Hilbe M, Teleki A, Knijnenburg JTN, Ehrensperger F, Hurrell RF, Pratsinis SE, Langhans W, Zimmermann MB: Iron from nanocompounds containing iron and zinc is highly bioavailable in rats without tissue accumulation. Nat Nanotechnol 2010, 5:374-380

77. Espita PJP, Soares NFF, Coimbra JSR, de Andrade NJ, Medeiros EAA: Zinc oxide nanoparticles: synthesis, antimicrobial activity and food packaging applications. Food Bioprocess Technol 2012, 5:1447-1464.

78. Lai SK, Wang YY, Hanes J: Mucus-penetrating nanoparticles for drug and gene delivery to mucosal tissues. Adv Drug Deliv Rev 2009, 61:158-171.

79. Paek HJ, Lee YJ, Chung HE, Yoo NH, Lee JA, Kim MK, Lee JK, Jeong J, Choi SJ: Modulation of the pharmacokinetics of zinc oxide nanoparticles and their fates in vivo. Nanoscale 2013, 5:11416-11427.

80. Chung HE, Yu J, Baek M, Lee JA, Kim MS, Kim SH, Maeng EH, Lee JK, Jeong J, Choi SJ: Toxicokinetics of zinc oxide nanoparticles in rats. J Phys: Conf Ser 2013, 429:012037.

81. Baek M, Chung HE, Yu J, Lee JA, Kim TH, Oh JM, Lee WJ, Paek SM, Lee JK, Jeong J, Choy JH, Choi SJ: Pharmacokinetics, tissue distribution, and excretion of zinc oxide nanoparticles. Int J Nanomedicine 2012, 7:3081-3097.

82. Cohen J, Deloid G, Pyrgiotakis G, Demokritou P: Interactions of engineered nanomaterials in physiological media and implications for in vitro dosimetry. Nanotoxicology 2013, 7:417-431.

83. Brown RP, Delp MD, Lindstedt SL, Rhomberg LR, Beliles RP: Physiological parameter values for physiologically based pharmacokinetic models. Toxicol Ind Health 1997, 13:407-484.

84. Schoeffner DJ, Warren DA, Muralidara S, Bruckner JV, Simmons JE: Organ weights and fat volume in rats as a function of strain and age. J Toxicol Environ Health A 1999, 56:449-462.

85. Jaki T, Wolfsegger MJ: Estimation of pharmacokinetic parameters with the R package PK. Pharm Stat 2011, 10:288-294.

doi:10.1186/s12989-014-0044-6

Cite this article as: Konduru et al:: Bioavailability, distribution and clearance of tracheally-instilled and gavaged uncoated or silica-coated zinc oxide nanoparticles. Particle and Fibre Toxicology 2014 11:44.

\section{Submit your next manuscript to BioMed Central and take full advantage of:}

- Convenient online submission

- Thorough peer review

- No space constraints or color figure charges

- Immediate publication on acceptance

- Inclusion in PubMed, CAS, Scopus and Google Scholar

- Research which is freely available for redistribution

Submit your manuscript at www.biomedcentral.com/submit
C Biomed Central 